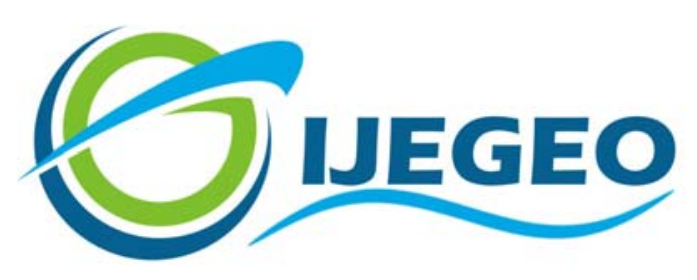

International Journal of Environment and Geoinformatics (IJEGEO) is an international, multidisciplinary, peer reviewed, open access journal.

\title{
Positioning Structural Height Restrictions: An Implication from Geo Observation Data around a Proposed Airport, Ido-Osun, Southwestern Nigeria
}

\author{
Jimoh RAFIU, Yusuf O. AFONJA, Solihu O. OLAOSEGBA, Benjamin I. \\ AJISAFE., Latifat O. OYELAKIN
}

\section{Chief in Editor}

Prof. Dr. Cem Gazioğlu

Co-Editors

Prof. Dr. Dursun Zafer Şeker, Prof. Dr. Şinasi Kaya, Prof. Dr. Ayşegül Tanık and Assist. Prof. Dr. Volkan Demir

Editorial Committee (August 2020)

Assos. Prof. Dr. Abdullah Aksu (TR), Assit. Prof. Dr. Uğur Algancı (TR), Prof. Dr. Bedri Alpar (TR), Prof. Dr. Lale Balas (TR), Prof. Dr. Levent Bat (TR), Prof. Dr. Paul Bates (UK), İrşad Bayırhan (TR), Prof. Dr. Bülent Bayram (TR), Prof. Dr. Luis M. Botana (ES), Assos. Prof. Dr. Gürcan Büyüksalih (TR), Prof. Dr. Nuray Çağlar (TR), Prof. Dr. Sukanta Dash (IN), Dr. Soofia T. Elias (UK), Prof. Dr. A. Evren Erginal (TR), Assoc. Prof. Dr. Cüneyt Erenoğlu (TR), Dr. Dieter Fritsch (DE), Prof. Dr. Çiğdem Göksel (TR), Prof.Dr. Lena Halounova (CZ), Prof. Dr. Manik Kalubarme (IN), Dr. Hakan Kaya (TR), Assist. Prof. Dr. Serkan Kükrer (TR), Assoc. Prof. Dr. Maged Marghany (MY), Prof. Dr. Michael Meadows (ZA), Prof. Dr. Nebiye Musaoğlu (TR), Prof. Dr. Masafumi Nakagawa (JP), Prof. Dr. Hasan Özdemir (TR), Prof. Dr. Chryssy Potsiou (GR), Prof. Dr. Erol Sarı (TR), Prof. Dr. Maria Paradiso (IT), Prof. Dr. Petros Patias (GR), Prof. Dr. Elif Sertel (TR), Prof. Dr. Nüket Sivri (TR), Prof. Dr. Füsun Balık Şanlı (TR), Prof. Dr. Uğur Şanlı (TR), Duygu Ülker (TR), Prof. Dr. Seyfettin Taş (TR), Assoc. Prof. Dr. Ömer Suat Taşkın (US), Dr. İnese Varna (LV), Dr. Petra Visser (NL), Prof. Dr. Selma Ünlü (TR), Assoc. Prof. Dr. İ. Noyan Yilmaz (AU), Prof. Dr. Murat Yakar (TR), Assit. Prof. Dr. Sibel Zeki (TR)

Abstracting and Indexing: TR DIZIN, DOAJ, Index Copernicus, OAJI, Scientific Indexing Services, International Scientific Indexing, Journal Factor, Google Scholar, Ulrich's Periodicals Directory, WorldCat, DRJI, ResearchBib, SOBIAD 


\title{
Positioning Structural Height Restrictions: An Implication from Geo Observation Data around a Proposed Airport, Ido-Osun, Southwestern Nigeria
}

\author{
Jimoh Rafiu, ${ }^{1}$ (D) Yusuf O. Afonja ${ }^{2}$ (D), Solihu O. Olaosegba ${ }^{2}$ (D), Benjamin I. Ajisafe ${ }^{2}$ (D) \\ Latifat O. Oyelakin ${ }^{2}$ \\ ${ }^{1}$ Geomodeling and Geoexplore Consultants, Lagos State, Nigeria. \\ 2 Surveying and Geoinformatics Department, Federal School of Surveying, Oyo State, \\ Nigeria \\ * Corresponding author: Jimoh, R.. \\ E-mail: geomodgeoexploreconsultants@gmail.com

\begin{abstract}
Geospatial data has been applied for setting structural height restriction around the proposed MKO Abiola international Airport in Ido-Osun, Osun State. The study aimed at using geovisualisation method for guiding structural height restriction around the airport. In Nigeria, there is a growing demand for Airports and safety is paramount to aviation industry as calamity is irreversible. In respect of this, precautionary measures are better emplaced at inception to safeguard the industry as much as possible. For example, failure because of engine faults in flight cannot be completely erased, at least, planes hitting buildings due to either low altitude of the airplane or excessive height of structures could be totally abated. Data used for this study involved Geospatially acquired data obtained through primary and secondary methods. The data were processed and a $2 \mathrm{~km}$ buffer zone was created around the proposed airport for analysis. Modelling of the study was done to relatively decipher the height relationship between the airport runway and the buffer zone. Hypotenuse theorem was used and available data, airplane altitude along various directions were calculated in relation to the mean sea level through which proposed heights restrictions were made for structures within the buffer zone in the study area. It was scientifically deduced that using of only number of building ,floors and other structures, the height above earth surface are not enough to set such height restriction, instead, elevations of adjoining land should also be a striking factor taken into set structural height restriction aided by Geo observation data.
\end{abstract}

Keywords: Geospatial Data, Positioning, Structural Heights Restrictions, Geovisualization

\section{Introduction}

Restrictions should be established on the heights of buildings, antennas, trees and other objects as necessary to protect the airspace needed for safe operation of the airport and aircraft. The law that regulate restrictions on building height around airports in Nigeria treats building heights as the vertical distance between the floor of the ground storey to the highest point on the roof of such building. The runways within most of Nigerian Airports have a lower elevation as compared to airport environments. The proposed MKO Abiola international Airport at Ido-Osun in Osun State is of no exception. Data visualization, the use of images to represent information, is only now becoming properly appreciated for the benefits it can bring to business. It provides a powerful means both to make sense of data and to then communicate what is discovered to others. Despite their potential, the benefits of data visualization are undermined today by a general lack of understanding. Many of the current trends in data visualization are actually producing the opposite of the intended effect, confusion rather than understanding. User-oriented developments, often as an explicit reaction to technological developments, have stimulated scientific visualisation and exploratory data analysis. The cartographic discipline has reacted to these changes. New concepts such as dynamic variables, digital landscape models, and digital cartographic models have been introduced. Map-based multimedia and cartographic animation, as well as the visualisation of quality aspects of spatial data, is core topics in contemporary cartographic research (Kraak, 1999; Kaya et al., 2001). It is not a safe idea that planes hitting buildings is not a good idea, not for the plane, the passengers, the building structure and the building occupants. Therefore, it is necessary to not have tall buildings around airports especially in the take-off and landing areas. It is not so easy, though. Real estate for hotels and businesses around airports is premium and the best way to ensure maximum return on the property is to build taller buildings on a small footprint. The result is a struggle between the airlines, the Federal Airport Authority and the building owners or real estate professionals (Kaya and Gazioğlu, 2015). As recently as 2014, the FAA suggested lowering the height limits on buildings around airports. The FAA cited safety concerns for the change specifically pointing to situations related to engine loss on take-off or landing and how flights routes currently have to be altered specifically to avoid tall buildings. 
According Nigerian national Building Code of 2006, building height shall mean the vertical distance from grade to the top of the highest roof beams or coping of a flat roof, or to the average height of the highest gable of a pitched or hipped roof. The height of a stepped or terraced building is the maximum height of any segment of the building (Aydar, et al., 2016; Büyüksalih, et al., 2019; Büyüksalih and Gazioğlu, 2019). Considering the inherent problem with this, it is high time, the use of spatial data and visualisation technique are being deployed in setting building height limits around the airports. This will avail all the stakeholders to be convinced since they will also be able to visualise the theoretical facts used in setting such restrictions. In decision support, spatial data and visualisation techniques play a predominant role in fundamental ways: visualisation may be used to present spatial information. The results of spatial analysis operations can be displayed in well-designed maps easily understood by a wide audience. Questions such as 'what is?', or 'where is?', and 'what belongs together?' can be answered. The cartographic discipline offers design rules to help answer such questions through functions, which create proper well-designed maps (MacEachren 1994; Robinson et al 1994).In a planning environment the nature of two separate datasets can be fully understood, but not their relationship. A spatial analysis operation, such as (visual) overlay, combines both datasets to determine their possible spatial relationship. Questions like 'what is the best site?' or 'what is the shortest route?' can be answered. What is required are functions to access individual map components to extract information and functions to process, manipulate, or summarise that information (Bonham-Carter 1994). In several applications, such as those dealing with remote sensing data, there are abundant (temporal) data available.
Questions like 'what is the nature of the dataset?', or 'which of those datasets reveal patterns related to the current problem studied?', and 'what if . . .?' have to be answered before the data can actually be used in a spatial analysis operation. Functions are required which allow the user to explore the spatial data visually (for instance by animation or by linked views - MacEachren 1995; Peterson 1995). Approval of building plans around the airport environment were based on number of storeys to be built without taking into consideration elevation difference, floor height and rate of attaining altitude by different aircrafts that will be plying such Airport after completion. This will pose a lot of danger in the nearest future due to erection of high-rise building synonymous to airport environment. The study was therefore aimed at using spatial data and geovisualisation technique in determining the building height restrictions around the proposed MKO Abiola International Airport, Idiosun, Osun State Nigeria. The study applies a GIS's features of geospatial data and $2.5 \mathrm{D}$ visualization to achieve the overall objective.

\section{Study Area Description}

The study area is MKO Abiola International Airport located along Ede-Oshogbo Road in the ancient town of Ido-Osun, Osun State, Southwestern Nigeria as seen in figure 1 below. It covers approximately 351 hectares of land and lies within approximate geographical coordinates of latitude $7 \mathrm{o} 45^{\prime}$ to $7 \mathrm{o} 47^{\prime}$ and longitude $4 \mathrm{o}$ $28^{\prime}$ to $4 \mathrm{o} 30^{\prime}$ '.It is the current airport project that is being implemented at Ido-Osun, Ede North/ Egbedore Local Government Areas. The airport will serve human and cargo transportation, holds an interesting historic value being the site of one of the early airstrips in Nigeria.

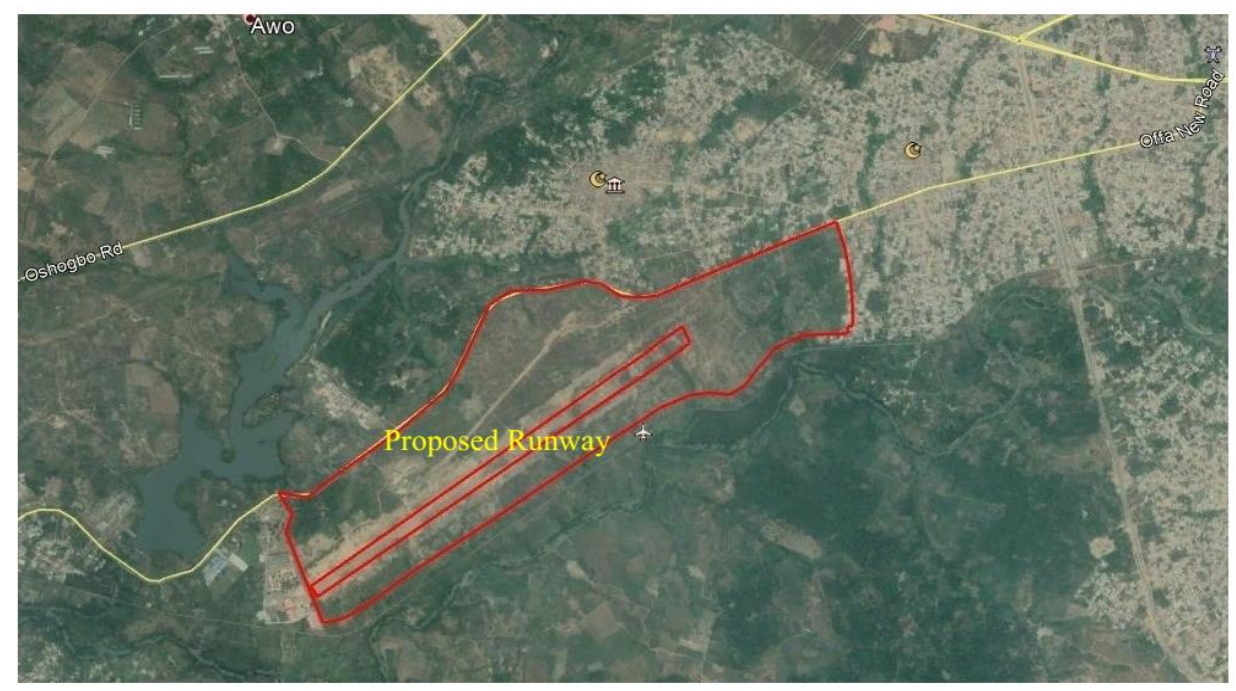

Fig. 1: Satellite Imagery of the Proposed MKO Abiola International Airport, Ido-Osun and its Environs.

\section{Methodology}

The methodology deployed for this study involved planning which entails study of the building code properly. Information as regards the rate of ascending and descending of aircraft were obtained from literatures. The acquisition of data was through topographic method, which culminated in the generation of topographic data. Real time kinematic mode of Differential Global Positioning System (DGPS) was adopted to pick the locational data in three (3) dimensional format, which was used to geo-rectify the SRTM data to be used. Integrity check was carried out on the available control points around the study area 
before the base receiver was set on one of them and site calibration was carried out. Data were picked randomly but at an interval of not less than $50 \mathrm{~m}$. The exercise covered the entire study area. Earth explorer was used to obtain SRTM data of one (1) arcsecond spacing of the study area for obtaining data for inaccessible area within the buffer zone of the study area. Google imagery of the area was downloaded from Google earth to enable further definition of the boundary of the study area. Two fundamental sources of data, which involved primary and secondary data, were used. The primary data utilizes the Land survey method adopted to acquire locational data of the airport and its two kilometer $(2 \mathrm{~km})$ buffer zone while the secondary data were picked randomly and at interval of $50 \mathrm{~m}$. The imageries (SRTM \& Google Imagery) of the area acquired through Earth Explorer

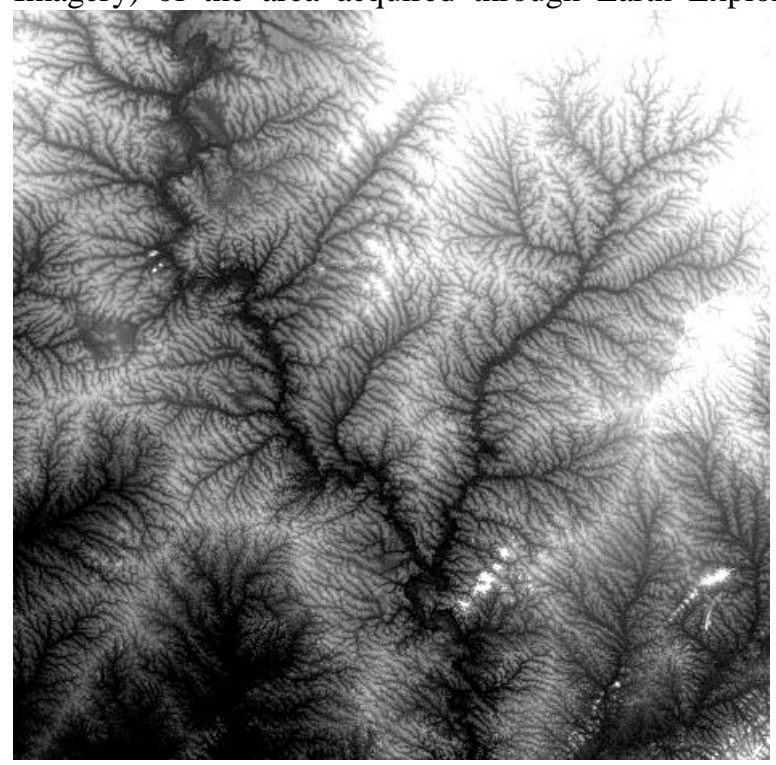

website and Google Pro application. Information as regards the current building height limits were obtained from Nigeria National Building Code of 2006.

\section{Digital Image Processing (DIP)}

The downloaded imagery of SRTM data was imported to Erdas Imagine 9.2 software. Digital Image processing was done on the imagery by carrying out Radiometric correction (Haze and reduction), Spectral correction (Decorrelation Stretch). The resultant product is displayed as the Original and corrected Imagery (SRTM) in figure 2.0 below. Also, the heights obtained from DGPS observations were used to geo-rectify the SRTM imagery in order to obtain more refined data for analysis.

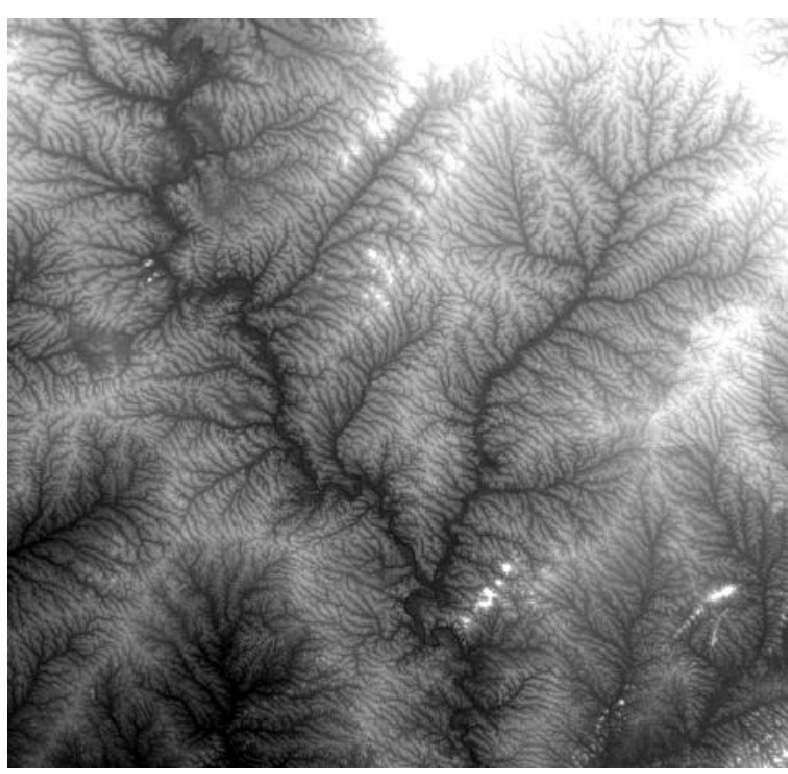

Fig. 2. Original and corrected Imagery (SRTM)
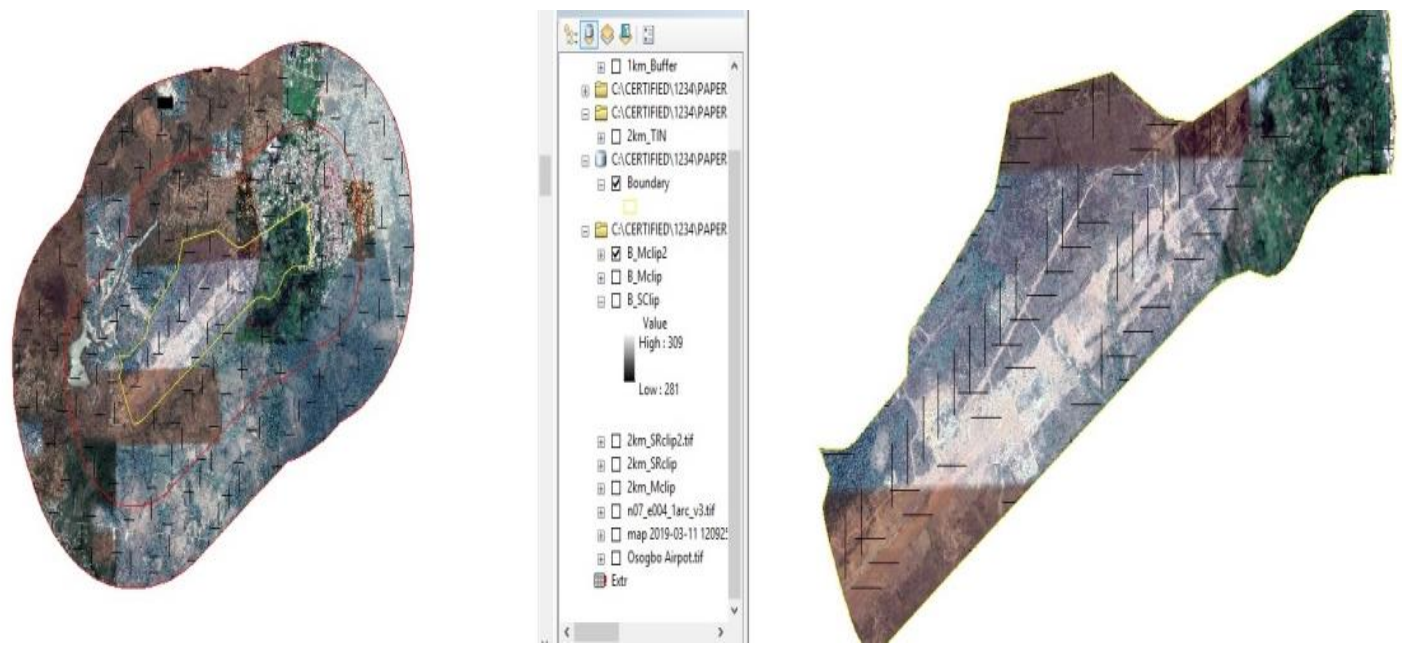

Fig. 3a.. Deliverables from the Google Earth Imagery after clipping 

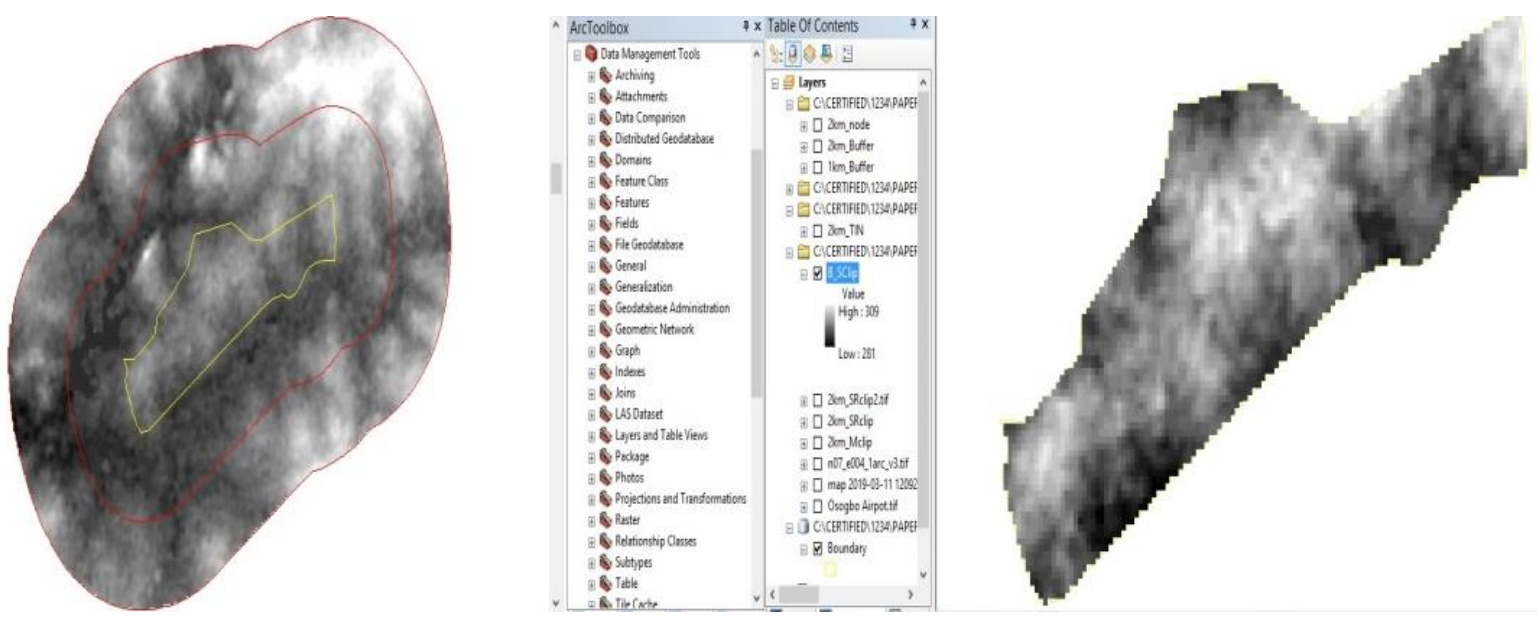

Fig. 3b. Results from the SRTM Imagery clipping.

Table 1.0: Height Accuracy Checks on SRTM Data

\begin{tabular}{|c|c|c|c|c|}
\hline Point Description & $\begin{array}{c}\text { Height (DGPS } \\
\text { data), m }\end{array}$ & $\begin{array}{c}\text { Height (SRTM } \\
\text { data), m }\end{array}$ & Difference & Remark \\
\hline Point1 & 295.658 & 295.076 & 0.582 & The difference is minimal \\
\hline Point2 & 311.624 & 312.346 & -0.722 & The difference is minimal \\
\hline Point3 & 301.594 & 301.904 & -0.310 & The difference is minimal \\
\hline Point4 & 292.182 & 291.512 & 0.670 & The difference is minimal \\
\hline Point5 & 306.437 & 306.879 & -0.442 & The difference is minimal \\
\hline
\end{tabular}

\section{Imagery Clipping}

The Google earth imager downloaded was imported to ArcGIS environment and georeferenced with set of coordinates from Google earth as well. The projection used was UTM zone 31 (Minna Datum). The boundary as verged before downloading was digitized to define the boundary of study area. The digitized area was buffered by 1 kilometer and 2 kilometers distances respectively. The imagery was then clipped thrice to the airport boundary and each of the buffer zone as seen in figure 3a. The corrected image was imported and transformed on ARCGIS 10.2. The airport boundary and the $1 \mathrm{~km}$ and $2 \mathrm{~km}$ buffer zone were also clipped out of the SRTM image. The result is shown in figure $3 \mathrm{~b}$. Each of the clipped images (Airport boundary, $1 \mathrm{~km}$ Buffer zone and $2 \mathrm{~km}$ buffer zone) were saved differently.

\section{Checking Height Accuracy of SRTM Data}

Five points whose heights have been earlier determined by DGPS observation was used to verify the accuracy of heights from SRTM imagery after initial georectification. The table 1 below shows the comparison of such heights. Considering the kind of heights in consideration and area covered, the differences are minimal.

\section{Generation of Digital Surface Model}

Two separate (two and half Dimension) surface models were generated using the clipped SRTM data and survey data for the buffer zone and the study area respectively. The results were as shown in the figure 4 . Each of the other two (2) clipped boundaries $(1 \mathrm{~km}$ and $2 \mathrm{~km}$ buffer zones) were added by selecting 'add $2.5 \mathrm{~d}$ surface layer' under map menu.

\section{Results and Discussion}

From the building code, maximum of 12floor of building is allowed within the said buffer zone. Based on that, the following data were calculated based on some assumptions. Height of each floor (assumed) = $3.0 \mathrm{~m}$, Height of the roof (assumed) $=2.4 \mathrm{~m}$.Therefore, the total height of the 12-floor building $=(12 \mathrm{~m} \mathrm{x} \mathrm{3m)}+$ $2.4 \mathrm{~m}$ of roof $=38.4$ meters, Average elevation within the buffer zone $=300 \mathrm{~m}$ above mean sea level. Therefore, elevation at the top of the building will be $=38.4 \mathrm{~m}+$ $300 \mathrm{~m}=338.4 \mathrm{~m}$. Data of two (2) buildings with the above elevation was added to the $2.5 \mathrm{~d}$ surface layer and the resulting $2.5 \mathrm{D}$ surface model is shown figure 5 . Within the first $500 \mathrm{~m}$ slope, distance a 30 inclination airplane would cover approximately $500 \mathrm{~m}$ horizontal distance and $26 \mathrm{~m}$ altitude. Such an altitude with the average elevation of the airport runway of $289 \mathrm{~m}$, the altitude from the mean sea level will be $315 \mathrm{~m}$. 


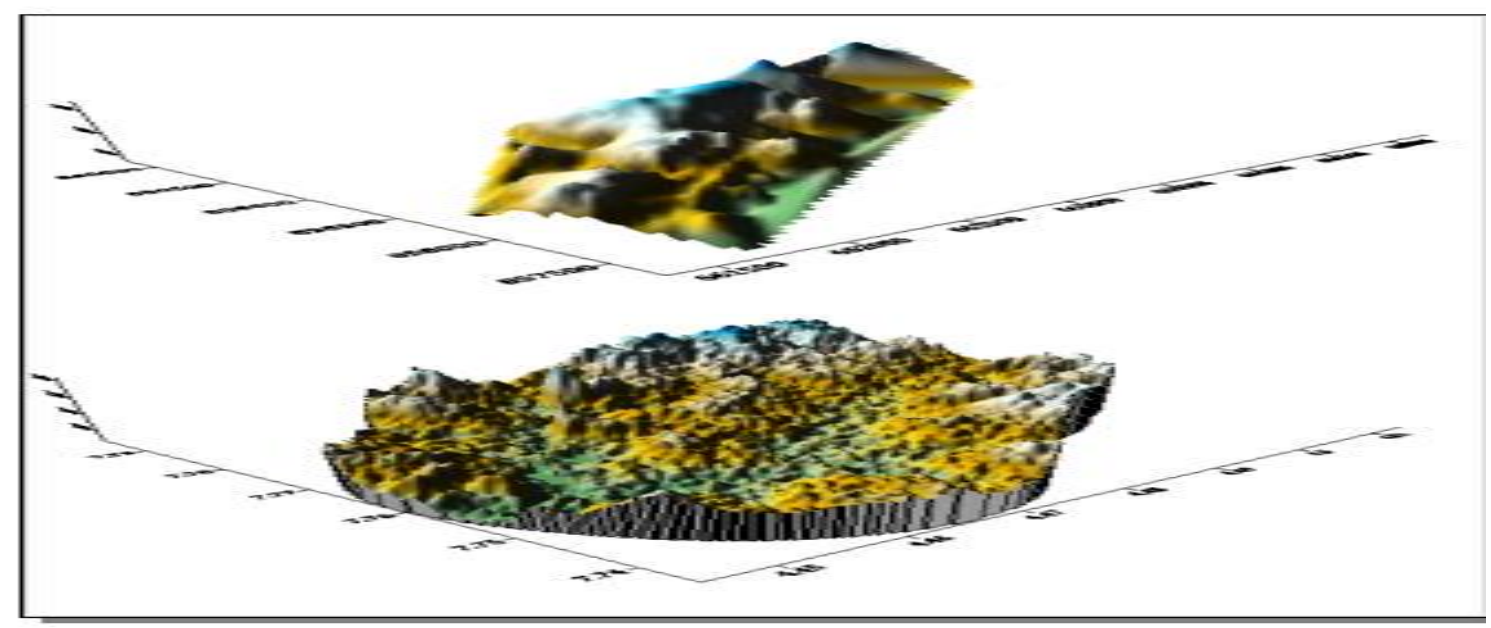

Fig. 4. Two and Half (2.5) D Surface Models of Airport boundary and its $2 \mathrm{~km}$ buffer zone.

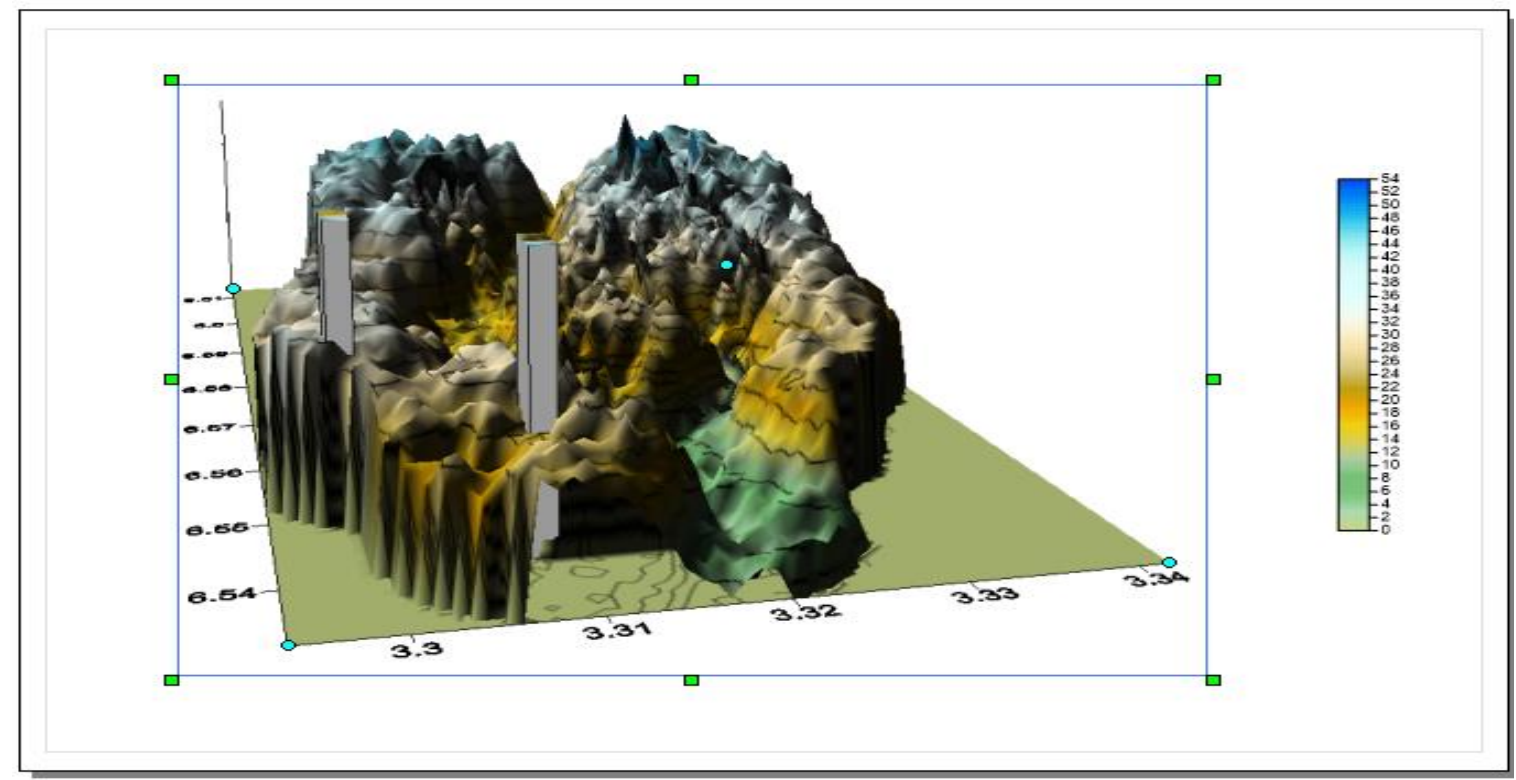

Fig. 5. 2.5D Surface Model of Airport boundary, its $1 \mathrm{~km}$ buffer zone and the two buildings.

In addition, within the first $1000 \mathrm{~m}$ slope distance a 30 inclination airplane would cover approximately 1000m horizontal distance and $52 \mathrm{~m}$ altitude. Such an altitude with the average elevation of the airport runway of $289 \mathrm{~m}$, the altitude from the mean sea level will be $341 \mathrm{~m}$. Comparing this to the height of the building above MSL determined above $(338.4 \mathrm{~m})$, it could be seen that if there is any 30 inclination airplane in that airport, there would not be sufficient clearance between building of 12 floors and the position of the airplane .Two options are available, either to reduce further the current height limitation or to deny operating airplane with such low inclination angle.

By world standard, to avoid effect of vibration of airplane on our buildings, there should be a minimum clearance of $500 \mathrm{feet}(150 \mathrm{~m})$. Looking at the table again, 150 inclination airplanes can only attained the total altitude from mean sea level of $418 m(129 m+189 m)$ which could not provide the required $150 \mathrm{~m}$ clearance. This means even before the world standard can be met, all surfaces and structures should have elevation below mean sea level. As seen in figure 6, the following terms were considered in determining the rate of altitude ascension and corresponding distance using 30 to 150 inclination angles (minimum and maximum aircraft inclination angle of ascension around the world) which includes : Thrust force which is the force at which the aircraft move through the air, Drag Force that attempt to pull back such aircraft, weight of the aircraft which also pull back such aircraft, angle of inclination of ascension of the aircraft, Slope distance of covered by the aircraft within specific time, Corresponding Horizontal Distance covered by the aircraft within the same time and the Vertical distance (altitude attained) covered within such slope distance. Using inclination angles 3, 5, 7, 9, 11, 13 and 15 and slope distances $0.5 \mathrm{~km}, 1 \mathrm{~km}, 1,5 \mathrm{~km}$ and $2 \mathrm{~km}$, then the Tables 2 shows the corresponding altitudes and horizontal distances for each inclination angles using the following formulas: Opposite $=$ Altitude $=$ Hypotenuse $\mathrm{x}$ Sin $\theta$, Adjacent $=$ Horizontal Distance Altitude $=$ Hypotenuse $\mathrm{x} \operatorname{Cos} \theta$. 

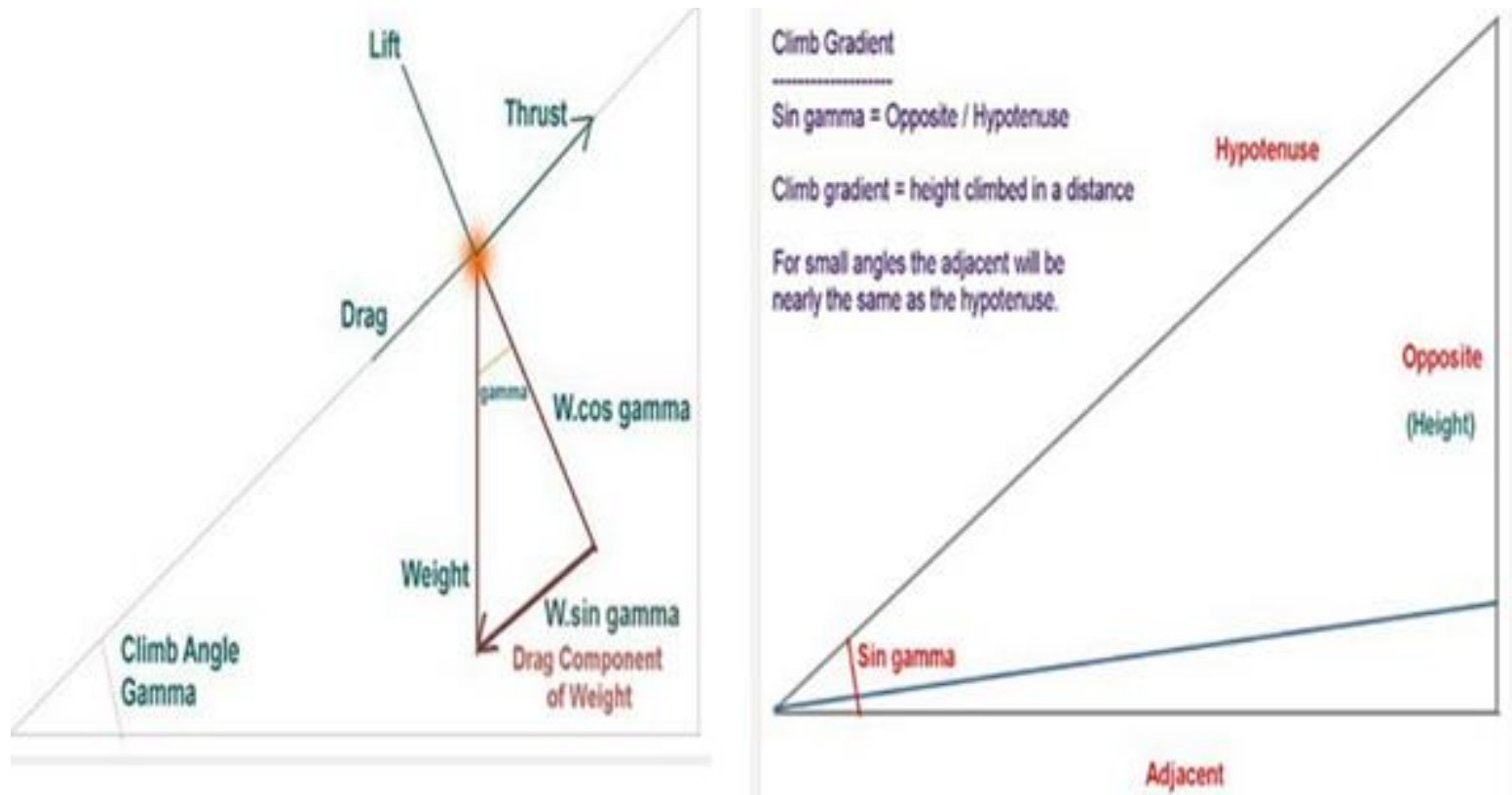

Fig. 6. Opposite $=$ Altitude/Height, Adjacent $=$ Horizontal Distance and Hypotenuse $=$ Slope Distance .

Table 2. Altitude determination at $0.5,1,1.5$ and $2 \mathrm{~km}$ Slope distances

\begin{tabular}{|c|c|c|c|c|}
\hline \multirow{2}{*}{$\begin{array}{c}\text { INCLINATION } \\
\text { ANGLE }\left({ }^{\circ}\right)\end{array}$} & \multicolumn{2}{|c|}{ SLOPE DISTANCES (m) } & \multirow[b]{2}{*}{1500} & \multirow[b]{2}{*}{2000} \\
\hline & 500 & 1000 & & \\
\hline \multicolumn{5}{|c|}{ ALTITUDE ATTAINED (m) } \\
\hline 3 & 26.2 & 52.3 & 78.5 & 104.7 \\
\hline 5 & 43.6 & 87.2 & 130.7 & 174.3 \\
\hline 7 & 60.9 & 121.9 & 182.8 & 243.7 \\
\hline 9 & 78.2 & 156.4 & 234.7 & 312.9 \\
\hline 11 & 95.4 & 190.8 & 286.2 & 381.6 \\
\hline 13 & 112.5 & 225.0 & 337.4 & 449.9 \\
\hline 15 & 129.4 & 258.8 & 388.2 & 517.6 \\
\hline \multicolumn{5}{|c|}{ SLOPE DISTANCES (m) } \\
\hline ANGLE $\left({ }^{0}\right)$ & 500 & 1000 & 1500 & 2000 \\
\hline \multicolumn{5}{|c|}{ HORIZONTAL DISTANCE COVERERD (m) } \\
\hline 3 & 499.3 & 998.6 & 1497.9 & 1997.3 \\
\hline 5 & 498.1 & 996.2 & 1494.3 & 1992.4 \\
\hline 7 & 496.3 & 992.5 & 1488.8 & 1985.1 \\
\hline 9 & 493.8 & 987.7 & 1481.5 & 1975.4 \\
\hline 11 & 490.8 & 981.6 & 1472.4 & 1963.3 \\
\hline 13 & 487.2 & 974.4 & 1461.6 & 1948.7 \\
\hline 15 & 483.0 & 965.9 & 1448.9 & 1931.9 \\
\hline
\end{tabular}

\section{Conclusion}

Restrictions should be established on the heights of buildings, antennas, trees, and other objects as necessary to protect the airspace needed for operation of the airports and aircraft. This is to guide against unforeseen situation that might arise against flight and humanity. Considering the advantage that the geospatial data and visualisation technique can contribute to the decisionmaking in setting building height limit around the airport, it was then concluded that decision-making criteria should not be limited to theoretical calculations, instead spatial data and visualization should be part of the decision support. Digital terrain modelling of the airport environs should be included in the dataset to be used in taking decisions while setting restriction for building height.

\section{Conflict of interest statement}

We declare that we have no conflict of interest. 


\section{References}

Aydar, SA, Yomralığlu, T., Özbek, Ed. (2016). Modeling Turkey National 2D Geo-Data Model as a CityGML Application Domain Extension in UML, International Journal of Environment and Geoinformatics (IJEGEO), 3(3):1-10.

Bonham-Carter, G.F. (1994). Geographical Information Systems for Geo-Scientists: Modelling With GIS. New York, Pergamon Press

Büyüksalih, İ., Alkan, M., Gazioğlu, C. (2019). Design for 3D city model management using remote sensing and GIS: A case study for the Golden Horn in Istanbul, Turkey, Sigma 37 (4), 1447-1462.

Büyüksalih, İ., Gazioğlu, C. (2019). New Approach in Integrated Basin Modelling: Melen Airborne LIDAR, International Journal of Environment and Geoinformatics (IJEGEO), 6(1):22-32.

Federal Government of Nigeria, FGN (2006). National Building Code. Cape Town, Lexis Nexis Butterworths

Kaya, H., Gazioğlu, C. (2015). Real Estate Development at Landslides, International Journal of Environment and Geoinformatics (IJEGEO), 2(1):62-71.

Kaya, Ş., Gazioğlu, C., Musaoğlu, N., Göksel, Ç. (2001). Examining The Land-Use Classes By Means of digital Elevation Model and Remotely Sensed Data,Observing our Environment from space. New solution for new millennium. Proceedings of the 21st EARSel Symposium, Paris, France, 14-16 May 2001, Vol. 21, $379 p$.

Kraak, M.J. (1999). Visualising spatial distributions. In P.A. Longley, M.F. Goodchild, D.J. Maguire \& D.W. Rhind (Eds.), Geographical Information Systems: Principles and Technical Issues, Vol. 1 (2nd Edition, P157). New York, John Wiley \& Sons, Inc.

MacEachren, A.M. (1994). Some Truth with Maps: A Primer on Design and Symbolization. Washington DC, Association of American Geographers

MacEachren, A.M. (1995). How maps work. New York, Guilford Press

Peterson, M.P. (1995). Interactive and animated cartography. New Jersy, Englewood Cliffs, PrenticeHall

Robinson, A.H., Morrison, J.L., Muehrcke, P.C., Kimerling, A.J. Guptill, S.C. (1994). Elements of cartography, 6th edition. New York, John Wiley \& Sons Inc. 